\title{
Pengaruh Jumlah Uang Beredar dan Pertumbuhan Ekonomi Terhadap Kinerja Reksadana Saham
}

\author{
Amilia Paramita Sari \\ Fakultas Ekonomi Universitas Batanghari \\ Correspondence email: amilia.paramita.sari@ unbari.ac.id
}

\begin{abstract}
This research seeks to verify and explain the influence the amount of money supply and economic growth in the performance of mutual stock funds in Indonesia. While the method used is a method of multiple linear regression analysis. The data used in this study is Time Series Period from January 2014 to December 2018. Studies find that simultaneously shows a significant effect about $74.7 \%$ the amount of money supply and economic growth impact on the performance of mutual stock funds in Indonesia. It was found that a significant effect on performance of mutual stock funds is the amount of money supply, whereas economic growth has no significant influence.
\end{abstract}

Keywords: amount of money supply (M2), gross domestic product (GDP), performance of mutual stock funds (NAV)

\section{PENDAHULUAN}

Pada era modernisasi saat ini melakukan investasi menjadi semakin penting bagi masyarakat. Dalam berinvestasi harus memperhatikan hal-hal sebagai berikut, yaitu return (keuntungan) yang akan diperoleh dan risk (risiko) yang mungkin akan terjadi. Menurut Pratomo \& Nugraha (2005), kesulitan utama yang dihadapi pemodal ketika berinvestasi di pasar saham yaitu pemodal harus melakukan berbagai analisa dan memonitor kondisi pasar secara terus-menerus yang sangat menyita waktu. Oleh karena itu, dengan semakin sulitnya berinvestasi saham langsung di bursa efek dan semakin berkembangnya inovasi di pasar modal maka munculah suatu alternatif produk investasi portofolio di pasar modal yaitu reksadana. Reksadana merupakan salah satu alternatif investasi bagi masyarakat pemodal. Reksadana dirancang sebagai sarana untuk menghimpun dana dari masyarakat, khususnya pemodal kecil, dan pemodal yang tidak memiliki banyak waktu dan keahlian untuk menghitung risiko atas investasi mereka.

Undang-Undang Pasar Modal No. 8 Tahun 1995, pasal 1 ayat (27) didefinisikan bahwa reksadana adalah wadah yang dipergunakan untuk menghimpun dana dari masyarakat pemodal untuk selanjutnya diinvestasikan dalam portofolio efek oleh manajer investasi. Hal tersebut semakin memberikan kemudahan kepada investor dalam berinvestasi di pasar saham, dikarenakan dikelola manajer investasi yang sudah profesional. Dalam memilih produk reksadana saham, maka produk reksadana saham mana yang dapat menghasilkan keuntungan di masa yang akan datang, investor sebaiknya melakukan analisis dan evaluasi terhadap kinerja suatu produk reksadana agar keuntungan yang optimal bisa didapatkan. Metode evaluasi kinerja portofolio secara khusus yaitu dengan mengukur risk dan return dari portofolio investasi reksadana yang bersangkutan. Terdapat 3 metode penghitungan kinerja reksadana, antara lain: metode Sharpe, metode Treynor, dan metode Jensen (Pratomo \& Nugraha, 2005: 195). Agar dapat melihat kinerja reksadana saham yang baik, terdapat beberapa variabel yang dapat menjadi pertimbangan investor dalam memilih berinvestasi pada produk reksadana saham, antara lain: Jumlah Uang yang Beredar (JUB) dan Pertumbuhan Ekonomi, dalam penelitian ini diwakilkan dengan Gross Domestic Product (GDP). Sedangkan kinerja reksadana saham diwakilkan dengan Nilai Aktiva Bersih (NAB).

Reksadana saham merupakan jenis reksadana yang memiliki return dan risk paling tinggi serta mengalami fluktuasi yang tertinggi dibandingkan dengan jenis reksadana yang lainnya, sehingga peneliti tertarik memilih reksadana saham sebagai sampel pada penelitian ini. Tujuan penelitian ini yaitu untuk memperkenalkan kepada calon investor bahwa produk reksadana saham memiliki keuntungan yang cukup besar, salah satunya pembelianya sangat terjangkau serta kemudahan dalam pengelolaanya. Selain itu, tujuan penelitian ini adalah untuk menunjukkan faktor apa yang mempengaruhi kinerja reksadana saham yang baik atau buruk agar calon investor dapat memperoleh keuntungan yang optimal. 


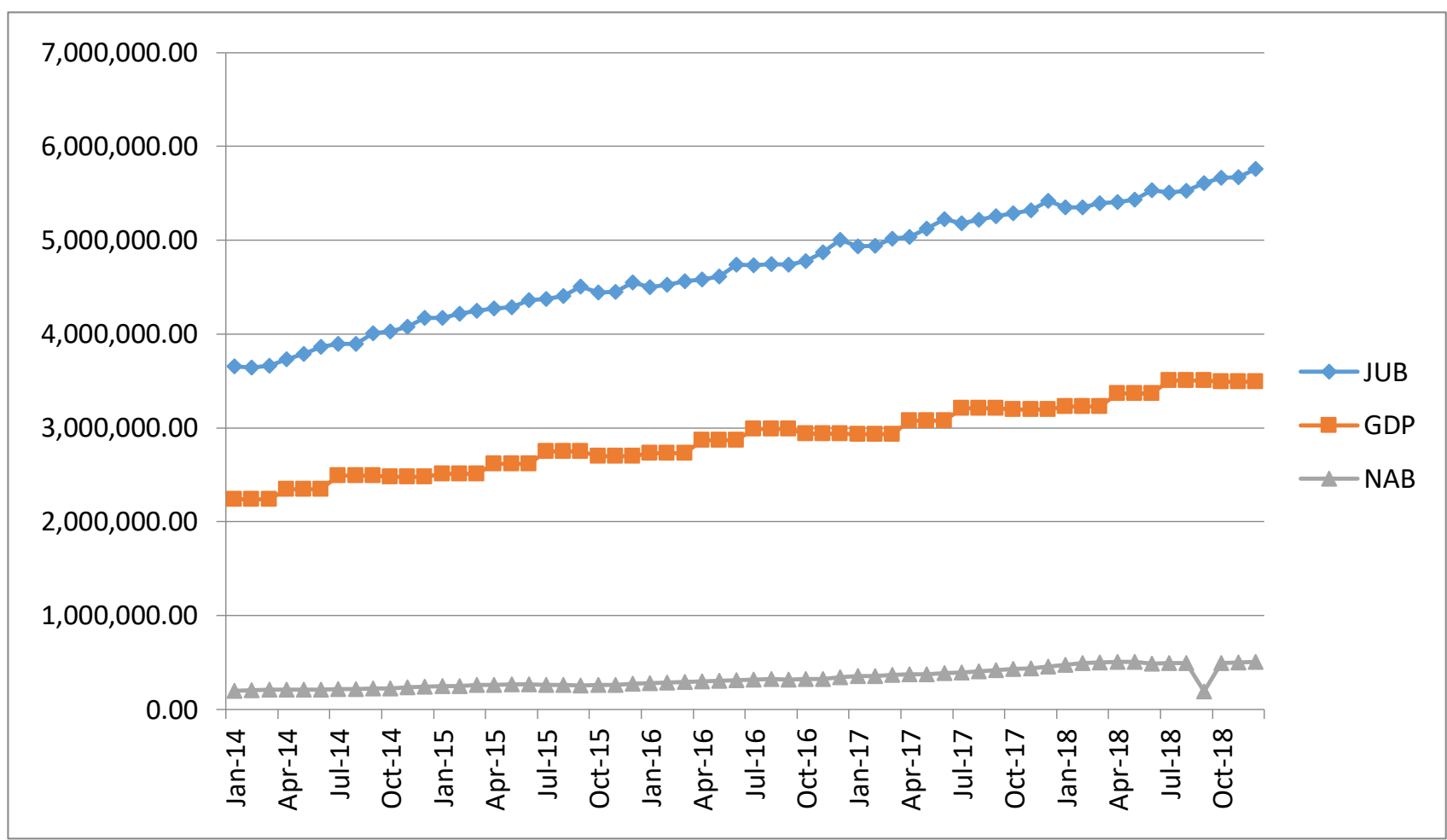

Sumber : Badan Pusat Statistik, Kementerian Pergadangan dan Otoritas Jasa Keuangan (data diolah), 2019

\section{Gambar 1.}

Grafik Perkembangan Jumlah Uang Beredar dan Gross Domestic Product (dalam milyaran rupiah)

Tujuan yang ingin dicapai dalam penelitian ini adalah untuk mengetahui apakah kinerja reksadana saham dapat menjadi penjelas hubungan antara jumlah uang beredar dengan Gross Domestic Product. Perbedaan penelitian ini dengan penelitian sebelumnya adalah pada sampel, yaitu produk reksadana saham yang digunakan adalah reksadana saham per unit yang sudah dipublikasikan secara umum di Otoritas Jasa Keuangan (OJK) selama tahun 2014-2018. Periode peneltian yang digunakan dimulai pada Bulan Januari 2014 sampai dengan Desember 2018. Variabel independen yang digunakan adalah jumlah uang yang beredar dan Gross Domestic Product pada nilai aktiva bersih.

\section{Tinjauan Pustaka}

Menurut Lina (2015) Investasi merupakan bagian dari perencanaan keuangan yang sangat penting dilakukan agar dapat memaksimalkan potensi uang serta mencapai suatu tujuan keuangan. Menurut Tandelilin (2010) reksadana adalah wadah yang berisi sekumpulan sekuritas yang dikelola oleh perusahaan investasi dan dibeli oleh investor. Menurut jenisnya investasi nya terdapat empat reksadana, antara lain : reksadana saham dimana memiliki tingkat return dan risiko paling besar, reksadana campuran, reksadana pendapatan tetap, dan yang terakhir yaitu reksadana pasar uang dimana memiliki tingkat return dan risiko paling kecil (Pratomo \& Nugraha, 2005) Berikut ini merupakan penjelasan dari masing -masing jenis reksadana:

1. Reksadana pasar uang adalah reksadana yang berinvestasi $100 \%$ pada surat berharga dengan masa jatuh temponya kurang dari satu tahun. Contohnya adalah deposito, tabungan, obligasi yang akan jatuh tempo dalam jangka waktu kurang dari satu tahun, dan obligasi yang diterbitkan dengan jangka waktu kurang dari satu tahun.

2. Reksadana pendapatan tetap adalah reksadana yang berinvestasi minimal $80 \%$ pada surat hutang dengan ketentuan pihak berutang akan membayar sejumlah kupon dan pokok pinjaman dalam jangka waktu yang telah disepakati.

3. Reksadana saham adalah reksadana yang berinvestasi minimal $80 \%$ pada saham. Reksa dana ini termasuk reksadana yang paling sulit untuk melakukan penyesuaian terhadap suatu kondisi siklus ekonomi. Reksadana saham akan mengalami kemunduran dalam kondisi depressionserta akan mengalami kejayaan pada kondisi ekonomi recovery (Samsul, 2015). 
4. Reksadana campuran adalah reksadana yang harus berinvestasi berdasarkan komposisi pasar uang, obligasi, dan saham dengan ketentuan maksimum 79\% di setiap instrumennya. Menurut Samsul (2015), reksadana ini merupakan reksadana yang paling fleksibel daripada yang lainnya dalam penyesuaian pada setiap kondisi ekonomi, hal ini dikarenakan dapat melakukan shiftingsecara drastis dari saham menjadi obligasi atau dari obligasi menjadi saham.

Menurut Pratomo \& Nugraha (2005) seperti halnya wahana investasi lainnya, disamping mendatangkan peluang keuntungan, reksadana pun umumnya mengandung 2 jenis, yakni risiko kerugian karena berkurangnya nilai NAB/Unit yaitu adanya perubahan kondisi ekonomi, politik termasuk juga kondisi sosial (adanya bencana dll.) dan keamanan di dalam dan luar negeri yang dapat mempengaruhi kinerja perusahaan dan risiko likuiditas oleh yaitu risiko menyangkut kesulitan yang dihadapi manajer investasi jika sebagian besar pemegang unit melakukan penjualan kembali (redemption) atas unit-unit yang dipegangnya. Menurut Abbasi et al. (2012) terdapat 9 keuntungan dengan berinvestasi di reksadana, antara lain : Manajemen yang professional, biaya yang rendah, likuiditas yang tinggi, website yang baik dan profesional, penyebaran informasi yang lengkap yaitu dalam bentuk prospektus, pengawasan dapat dilakukan secara online, dan yang terakhir modal investasi dapat diversifikasi ke berbagai bentuk investasi seperti saham, obligasi, SBI dll.

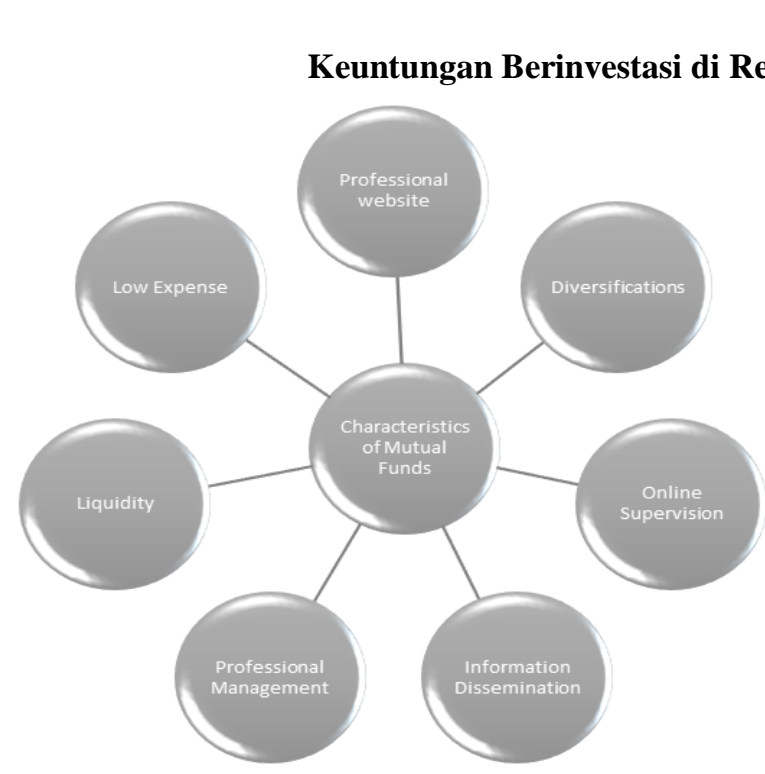

Sumber: Abbas et al. 2012.

Gambar 2.

ksadana dan Mekanisme Kerja Reksadana

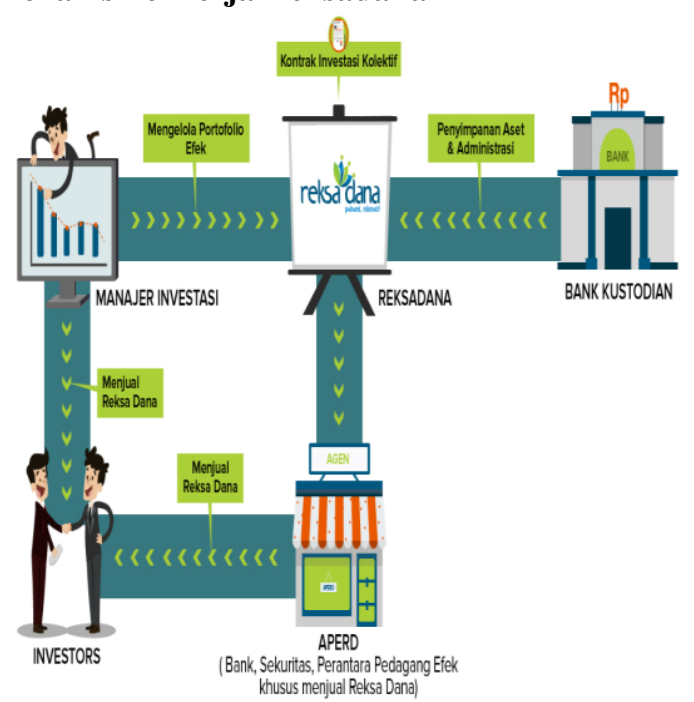

Sumber : Otoritas Jasa Keuangan, 2019

Mekanisme kerja yang terjadi dalam reksadana, selain melibatkan Manajer Investasi, Bank Kustodian dan investor juga melibatkan pelaku (perantara) di pasar modal (broker) serta di pasar uang (bank) serta pengawasan yang dilakukan oleh Bapepam (saat ini menjadi OJK). Berikut ini mekanisme kerja dalam reksadana berbentuk Kontrak Investasi Kolektif (KIK) (Pratomo \& Nugraha, 2005). Kinerja Reksa Dana Saham Kinerja sebuah portofolio tidak bisa hanya melihat tingkat return yang dihasilkan portofolio tersebut, tetapi juga harus memperhatikan faktor-faktor lain seperti tingkat risiko portofolio tersebut. Dengan berdasarkan pada teori pasar modal, beberapa ukuran kinerja portofolio sudah memasukkan faktor return dan risiko dalam perhitungannya (Trisnopati \& Titik: 2015). Pada penelitian ini, meggunakan metode Sharpe dengan rumus sebagai berikut:

$S_{R D}=\left(K I N E R J A_{R D}-K I N E R J A_{R F}\right) / \alpha$

\section{Penelitian Terahulu}

Penelitian sebelumnya yang dilakukan oleh Rozak (2016), Hasil penelitian menunjukkan secara parsial variabel IHSG dan Jumlah Uang yang Beredar berpengaruh signifikan terhadap kinerja reksadana saham. Penelitian lain dilakukan oleh Maulana (2013), menunjukkan hasil yang berbeda dari penelitian Rozak. Hasil penelitian menunjukkan bahwa tingkat suku bunga SBI berpengaruh negatif signifikan, tingkat suku bunga SBI menurun ini memberikan dampak positif pada kinerja reksadana saham, jumlah uang yang 
beredar tidak memiliki pengaruh terhadap kinerja reksadana saham. Inflasi memiliki pengaruh negatif signifikan pada kinerja reksadana saham.

\section{Hipotesis}

$\mathrm{H}_{1}=$ Variabel jumlah uang beredar (M2) diduga berpengaruh signifikan terhadap kinerja reksadana saham di Indonesia periode 2014-2018

$\mathrm{H}_{2}=$ Variabel pertumbuhan ekonomi (GDP) diduga berpengaruh signifikan terhadap kinerja reksadana saham di Indonesia periode 2014-2018

\section{METODE}

Pendekatan dalam penelitian ini menggunakan pendekatan kuantitatif karena informasi atau data diwujudkan dalam bentuk angka dan dianalisis berdasarkan analisis statistik. Penelitian ini dilakukan pada reksadana saham yang sudah dipublikasikan secara umum pada Otoritas Jasa Keuangan selama periode tahun 2014 sampai dengan 2018. Data yang digunakan dalam penelitian ini adalah data sekunder yaitu sumber data yang diperoleh secara tidak langsung seperti dari website, publikasi dll. Jenis data yang digunakan adalah Data Time Series (Runtun Waktu) yakni jenis data yang terdiri atas variabel-variabel yang dikumpulkan menurut urutan waktu dalam suatu rentang waktu tertentu. Jika waktu dipandang bersifat diskrit (waktu dapat dimodelkan bersifat kontinu), frekuensi pengumpulan selalu sama (equidistant). Dalam kasus diskrit, frekuensi dapat berupa misalnya detik, menit, jam, hari, minggu, bulan atau tahun dan lainlain. Data penelitian yang digunakan adalah data bulanan, dimulai pada Bulan Januari 2014 sampai dengan Desember 2018. Sumber data dalam penelitian ini adalah reksadana saham yang terdaftar di OJK, yang diambil dari laman (https://reksadana.ojk.go.id), jumlah uang beredar yang diambil dari laman (https://www.bps.go.id), Gross Domestic Product yang diambil dari laman (https://www.kemendag.go.id). Sampel yang digunakan dalam penelitian ini adalah seluruh unit reksadana saham yang terdaftar dan aktif secara terus menerus di Otoritas Jasa Keuangan selama periode Januari 2014 sampai dengan Desember 2018. Teknik analisis data yang digunakan dalam penelitian ini adalah analisis statistik deskriptif dan analisis regresi linear berganda. Dalam penelitian ini, kinerja reksadana saham diukur dari besarnya return nilai aktiva bersih per unit reksadana untuk mendapatkan hasil kinerja reksadana. Kinerja reksadana diukur dari return yang dihasilkan. Return kinerja reksadana saham dihitung dengan rumus:

$R i=\frac{N A B_{t}-N A B_{t-1}}{N A_{t-1}}$

Keterangan: $\mathrm{Ri}=$ Tingkat pengembalian reksadana; NABt $=$ Nilai Aktiva Bersih akhir; NABt $-1=$ Nilai Aktiva Bersih Awal; Return jumlah uang yang beredar diukur dengan rumus sebagai berikut:

$\boldsymbol{R j}=\frac{I U B_{t}-J U B_{t-1}}{J U B_{t-1}}$

Keterangan: $\mathrm{Rj}=$ Tingkat pengembalian jumlah uang yang beredar; $\mathrm{JUBt}=$ jumlah uang yang beredar akhir; JUBt-1 = jumlah uang yang beredar Awal

Return Gross Domestic Product diukur dengan rumus sebagai berikut:

$R \boldsymbol{g}=\frac{G D P_{t}-G D P_{t-1}}{G D P_{t-1}}$

Keterangan: $\mathrm{Rg}=$ Tingkat pengembalian Gross Domestic Product; GDPt = Gross Domestic Product akhir; GDPt-1 = Gross Domestic Product Awal

\section{HASIL}

Uji normalitas data menunjukkan data terdistribusi normal karena memiliki nilai Asymp. Sign di atas 0,05 , yaitu sebesar 0,355. Pengujian asumsi klasik menunjukkan data tidak mengalami multikolinearitas karena semua variabel bebas memiliki nilai tolerance di atas 0,1 dan nilai VIF kurang dari 10. Data juga bersifat homoskedastis karena nilai uji Glejser menunjukkan probabilitas signifikan semua variabel be bas di atas tingkat kepercayaan 0,05. Data juga tidak mengalami autokorelasi karena nilai test Durbin-Watson $=$ 1,325, memenuhi persamaan dU $<\mathrm{DW}<4$-dU (yaitu $1,100<1,325<1,537$ ). Dengan demikian model regresi yang dibentuk layak digunakan untuk menyelesaikan permasalahan penelitian ini. Analisis statistik yang digunakan dalam penelitian ini adalah regresi linier berganda. Analisis ini digunakan untuk mengetahui besarnya pengaruh variabel independen yaitu JUB dan GDP terhadap variabel dependen yaitu NAB. 
Tabel 1.

Hasil Uji F

\begin{tabular}{clrrrrr}
\hline Model & Sum of Squares & df & Mean Square & F & Sig. \\
\hline Regression & 841173.456 & 2 & 420586.728 & 84.369 \\
Residual & 284149.232 & 57 & 4985.074 & & \\
Total & 1125322.688 & 59 & & \\
\hline
\end{tabular}

Sumber: data olahan

Uji F yang biasa disebut dengan uji simultan (secara keseluruhan), digunakan dalam penelitian untuk mengetahui pengaruh yang terjadi diantara variabel independen terhadap variabel dependen. Berdasarkan hasil dari Uji F pada tabel 1 dapat diketahui bahwa secara simultan JUB dan GDP berpengaruh signifikan. Hal ini dikarenakan nilai probabilitas dari uji $\mathrm{F}<0,05$ yaitu sebesar 0,000 .

Tabel 2.

Hasil Uji t

\begin{tabular}{lrrrrr}
\hline Variable & Coefficients & Std. Error & t-statistic & Prob. & \\
\hline C & 2420.503 & 77.207 & 31.351 & 0.000 \\
JUB & .000 & 0.000 & -3.298 & 0.002 \\
GDP & 0.584689 & 0.000 & -.053 & 0.958 \\
\hline
\end{tabular}

Sumber: data olahan

Pengaruh JUB Terhadap Kinerja Reksadana Saham Berdasarkan hasil pengujian hipotesis secara parsial yang telah dilakukan, Jumlah Uang yang Beredar memiliki nilai prob 0,002 < 0,05, maka sesuai dengan ketentuan bahwa $\mathrm{H}_{1}$ diterima yang dapat diartikan bahwa JUB mempunyai pengaruh signifikan terhadap kinerja reksadana saham. Sehingga dengan semakin banyaknya Jumlah Uang yang Beredar bagi produk reksadana dapat lebih leluasa dan memaksimalkan peran manajer investasi dalam menanamkan modal di berbagai portofolio investasi. Pengaruh GDP Terhadap Kinerja Reksadana Saham Berdasarkan hasil pengujian hipotesis secara parsial yang telah dilakukan, $G D P$ memiliki nilai prob 0,985 > 0,05, maka sesuai dengan ketentuan bahwa $\mathrm{H}_{2}$ ditolak yang dapat diartikan bahwa Gross Domestic Product tidak mempunyai pengaruh signifikan terhadap kinerja reksadana saham. Dengan semakin bagusnya kinerja sebelumnya, maka belum tentu berpengaruh terhadap kinerja reksadana di masa mendatang.

Tabel 3.

Koefisien Determinasi $\left(\mathbf{R}^{2}\right) \mathbf{U j i} \mathbf{R}^{2}$

\begin{tabular}{lllllll}
\hline $\mathbf{R}$ & $\mathbf{R}^{\mathbf{2}}$ & Adjusted R $^{\mathbf{2}}$ & Std. Error & Sig. $\mathbf{F}$ & DW & \\
\hline $\mathbf{0 . 8 6 5}$ & 0.747 & 0.739 & 70.6050582 & 0.000 & 1.325 \\
\hline
\end{tabular}

Sumber: data olahan

Hasil yang didapat dalam penelitian ini pada table 3 , bahwa nilai $\mathrm{R}^{2}$ adalah $0.747(74,7 \%)$. Artinya $74,7 \%$ perkembangan NAB reksadana saham dipengaruhi oleh JUB dan GDP, kemudian 25,3\% adalah dipengaruhi oleh faktor lain. Uji t yang dilakukan menyimpulkan bahwa JUB berpengaruh siginifikan terhadap NAB reksadana saham periode 2014 - 2018. Perkembangan JUB yang cenderung meningkat disebabkan masyarakat cenderung mengeluarkan uang di sektor konsumtif. Hasil tersebut mendukung penelitian yang telah dilakukan oleh Rozak (2016) yang menunjukkan bahwa Jumlah Uang yang Beredar berpengaruh signifikan terhadap kinerja reksadana saham. Berdasarkan uji t yang telah dilakukan, penelitian ini menyimpulkan nilai GDP tidak memiliki pengaruh signifikan bagi NAB reksadana saham periode 2014 2018. Hal ini bisa dikarenakan perkembangan GDP pada periode tersebut masih tergolong stabil dan wajar, sehingga tidak begitu berdampak pada keputusan investor dalam pengambilan keputusan berinvestasi. Uji F, penelitian ini menyimpulkan bahwa secara simultan (keseluruhan variabel)terjadi pengaruh yang signifikan oleh JUB dan GDP bagi NAB reksadana saham. Hasil tersebut bisa disebabkan oleh GDP yang secara parsial tidak memiliki pengaruh signifikan kepada NAB reksadana saham. Selain itu, hasil penelitian yang dilakukan oleh Maulana (2013) juga tidak sesuai dengan hasil penelitian ini. Dalam penelitian tersebut disimpuklan bahwa JUB secara parsial tidak memiliki pengaruh yang relevan bagi NAB reksadana saham. Perbedaan hasil tersebut dapat dikarenakan perbedaan jumlah variabel bebas dan perbedaan periode data yang digunakan. 


\section{SIMPULAN}

Simpulkan bahwa variabel jumlah uang yang beredar memiliki pengaruh signifikan terhadap kinerja reksadana saham di Indonesia, sedangkan variabel pertumbuhan ekonomi tidak berpengaruh signifikan terhadap kinerja reksadana saham di Indonesia. Meskipun demikian, secara simultan variabel independen tersebut secara bersama-sama berpengaruh signifikan terhadap kinerja reksadana saham di Indonesia. Variabel independen tidak signifikan menunjukkan bahwa jumlah uang yang beredar dan Gross Domestic Product tidak dapat menjadi acuan terhadap kinerja reksadana di masa yang akan datang. Keterkaitan variabel dana kelolaan terhadap salah satu prinsip ekonomi politik yaitu "core-periphery" adalah dengan bergantungnya dana kelolaan dari luar negeri dimana investor asing tersebut mendominasi jumlah modal di reksadana saham, maka pengaruh global sangat berdampak terhadap kinerja dari reksadana dan secara lebih luas menimbulkan. Saran bagi pemerintah dan perusahaan reksadana saham adalah perlunya melakukan sosialisasi terkait produk reksadana agar masyarakat mengerti apa itu reksadana, dapat menjelaskan bagaimana sistem keuntungan dan risiko dalam investasi di reksadana, serta menjelaskan kelebihan dan kekurangan dari reksadana. Reksadana merupakan salah satu alat investasi dan mampu menghasilkan keuntungan yang optimal di masa yang akan datang dibandingkan hanya menabung di Bank yang akan tergerus dengan inflasi.

\section{DAFTAR PUSTAKA}

Abasyn Journal of Social Sciences Vol 9(2), 211-219. Republik Indonesia. 1995. Undang-Undang No. 8 Tahun 1995 tentang Pasar Modal.

Abbasi et al. 2012. Effect of Fund Size on the Performance of Mutual Funds Evidence from Iran. Journal of Basic and Applied Scientific Research.

Lina, R. 2015. Bisa Berinvestasi dengan Gaji <Rp 5 Juta, Penebar Plus+. Yogyakarta.

Maulana, Akbar. 2013. Pengarih SBI, Jumlah Uang yang Beredar, Inflasi Terhadap Kinerja Reksadana Saham di Indonesia Periode 2004-2012, Jurnal Ilmu Manajemen Vol.1 No.3.

Nurmayanti M, Poppy dan Novita Indrawat.2010. Pasar-Pasar Analisis Investasi dan Portofolio. Citrabook Indonesia. Palembang

Kurniasih dan Johannes. 2015. Analisis Variabel Makroekonomi Terhdap Kinerja Reksadana Campuran, Jurnal Manajemen. Volume XIX, No. 136-151.

Pratomo, Eko Priyo., Nugraha, Ubaidillah. 2005. REKSADANA "Solusi Perencanaan Investasi di Era Modern”, Edisi Keempat. Jakarta: Gramedia Pustaka Utama.

Rozak, Abdul. 2016. Analisis Pengaruh Indeks Harga Saham Gabungan (IHSG) dan Jumlah Uang yang Beredar Terhadap Kinerja Reksadana Saham di Bursa Efek Indonesia, Conference On Management and Behavioral Studies. ISSN No. 2541 - 3400. eISSN No. 2541-2850.

Samsul, M. 2015. Pasar Modal \& Manajemen Portofolio. Penerbit Erlangga. Jakarta.

Sari, Amilia P. 2018. Analisis Faktor Fundamental dan Laba Akuntansi terhadap Harga Saham pada Sub Sektor Lembaga Pembiayaan di BEI, Jurnal Manajemen dan Sains Vol.3 No.1 April 2018.

Tandelilin, Eduardus. 2010. Portofolio dan Investasi Teori dan Aplikasi, Edisi Pertama. Yogyakarta: Kanisius.

Trisnopati, Titik Farida. 2015. Pengaruh Stock Selection, Market Timing, dan Ukuran Reksadana Terhadap Kinerja Reksadana Saham (Studi Kasus pada Reksadana Saham yang Terdaftar di Otoritas Jasa Keuangan (OJK) Periode 2011-2014). 